Case Reports in
Gastroenterology
Case Rep Gastroenterol 2021;15:352-358

DOI: 10.1159/000513801

Published online: March 12, 2021

(C) 2021 The Author(s)

Published by S. Karger AG, Basel

www.karger.com/crg

This article is licensed under the Creative Commons Attribution-NonCommercial 4.0 International License (CC BY-NC) (http://www.karger.com/Services/OpenAccessLicense). Usage and distribution for commercial purposes requires written permission.

\title{
Rare Etiology of Odynophagia in a Female Adolescent
}

\author{
Anastasios Koutsoumourakis ${ }^{a} \quad$ Asterios Gagalis $^{a} \quad$ Maria Fotoulaki $^{b}$ \\ Maria Stafylidou ${ }^{a}$ \\ ${ }^{a}$ First Department of Internal Medicine, Papageorgiou Teaching Hospital, \\ Thessaloniki, Greece; ${ }^{b}$ Fourth Department of Pediatrics, Papageorgiou Teaching Hospital, \\ Thessaloniki, Greece
}

\section{Keywords}

Herpes esophagitis · Adolescent $\cdot$ Immunocompetent $\cdot$ Acyclovir

\begin{abstract}
Herpes esophagitis (HE) is a rare condition in immunocompetent adolescents. However, it commonly occurs as a primary infection in younger individuals. Herein, we report a 16 -yearold female patient who had a history of fever for 5 days, odynophagia, and orolabial herpes infection for 7 days. Clusters of painful vesicles on an erythematous base on the lips, gingiva, and palate were observed on physical examination. Further, esophagogastroduodenoscopy revealed diffuse linear ulcerations in the distal esophagus. The patient then received the following treatment: intravenous (I.V.) acyclovir $5 \mathrm{mg} / \mathrm{kg}$ three times a day, I.V. omeprazole 40 mg two times a day, and acyclovir $5 \%$ cream four times a day. After 8 days of admission, the patient was discharged. A follow-up esophagogastroduodenoscopy was performed 7 weeks after discharge, and the results revealed that the esophageal mucosa had a normal appearance. The effect of antiviral treatment against HE remains unknown in these patients. Nevertheless, it is believed to accelerate the healing process in individuals with esophageal mucosal barrier damage. To the best of our knowledge, this case of a female adolescent with an intact immune system is the sixth case of herpes simplex esophagitis to be reported in the literature.




\section{Case Reports in Gastroenterology}

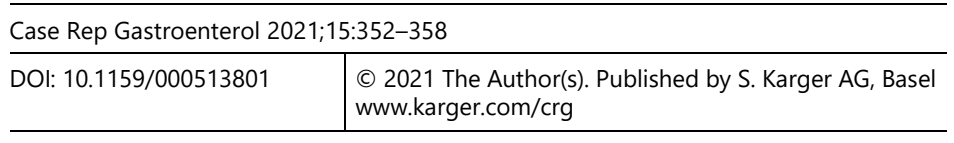

Koutsoumourakis et al.: Rare Etiology of Odynophagia in a Female Adolescent

\section{Introduction}

Herpes simplex viruses have a double-stranded DNA and are classified into two distinct types, which are as follows: herpes simplex virus 1 (HSV-1) and herpes simplex virus 2 (HSV2 ). They are transmitted after contact with infectious secretions that contain either HSV-1 (commonly detected in oral secretions) or HSV-2 (usually found in genital secretions). HSV-1 in the gastrointestinal tract frequently induces orofacial and esophageal herpetic lesions, and HSV-2 often causes perianal and rectal herpetic lesions [1]. The esophagus is commonly involved in patients with AIDS or an underlying malignancy, those receiving immunosuppressive therapy and, finally, terminally ill patients who underwent nasogastric intubation. Further, it is attributed usually to virus reactivation and rarely to primary infection [1].

The most common clinical features of herpes esophagitis (HE) are dysphagia, odynophagia, chest pain, and fever. Although the disease is usually self-limiting, severe complications, such as upper gastrointestinal hemorrhage and esophageal rupture, may be observed [1,2]. On endoscopy, HE can appear as discrete or continuous ulcers with superficial or deep appearance with or without overlying exudates or, even rarely, as necrotic changes in the mucosa in the middle and distal esophagus [3].

Diagnosis is confirmed using at least one of the following methods: serology, histopathology, immunohistochemistry, HSV isolation from oropharyngeal secretions or esophageal tissue culture, and HSV genome detection via polymerase chain reaction (PCR) using esophageal biopsy specimens. The characteristic histological findings of HE are the presence of eosinophilic intranuclear inclusion bodies (Cowdry type A inclusion bodies) and/or multinucleated giant cells with ground-glass nuclei in epithelial cells on hematoxylin and eosin staining [4]. Treatment with intravenous acyclovir may resolve symptoms. Valacyclovir and famciclovir can also be used in patients who can take oral medications. However, data on their effect against HE are limited [4].

\section{Case Presentation}

A 16-year-old female patient with a history of fever for 5 days, odynophagia, and orolabial herpes infection for 7 days visited the accident and emergency department. The patient had been previously treated with amoxicillin and famciclovir. Moreover, she had no significant surgical or medical history, including allergic disorders, gastroesophageal reflux disease, and eosinophilic esophagitis (EoE).

The patient was afebrile, anicteric, and slightly dehydrated. Physical examination revealed clusters of painful vesicles on an erythematous base on the lips, gingiva, and palate. However, the results of other clinical examinations were not remarkable. Esophagogastroduodenoscopy (EGD) was urgently performed, and results revealed diffuse linear ulcerations in the distal esophagus (Fig. 1). Multiple biopsy samples were collected from the edges of the ulcers. Results did not show the presence of tissue eosinophils. Moreover, the characteristic histopathologic features of $\mathrm{HE}$, such as multinucleated cells with overlapping nuclei and ground-glass appearance, were not observed [3]. Based on an extensive initial workup, the 


\section{Case Reports in Gastroenterology}

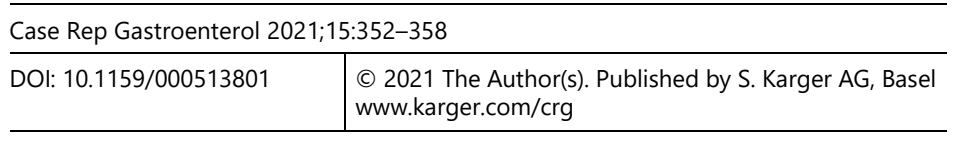

Koutsoumourakis et al.: Rare Etiology of Odynophagia in a Female Adolescent

patient did not present with candidiasis or hematological disorders, immunodeficiency, and viral disorders including HIV infection.

IgM and IgG, which are specific antigens against HSV, were not detected using enzymelinked immunosorbent assay. This phenomenon could be explained by the fact that our patient presented with a primary infection that was likely caused by local spread of the virus from the orolabial lesions. Thus, she was empirically treated with intravenous (I.V.) acyclovir $5 \mathrm{mg} / \mathrm{kg}$ three times a day, I.V. omeprazole $40 \mathrm{mg}$ two times a day, and acyclovir $5 \% \mathrm{cream}$ four times a day for concurrent orolabial herpes infection.

On day 2, the patient experienced significant clinical improvement and rapid recession of the orolabial lesions. On day 8 , she was discharged from the hospital with the following takehome medications: oral acyclovir $400 \mathrm{mg}$ three times a day and acyclovir $5 \%$ cream four times a day for another 6 days and oral omeprazole $40 \mathrm{mg}$ two times a day for another 7 weeks. A follow-up EGD was performed 7 weeks after discharge, and results revealed that the esophageal mucosa had a normal appearance (Fig. 2).

\section{Discussion}

HE is not common in immunocompetent adolescents. In this case, it was clinically suspected in a healthy individual who presented with odynophagia and a history of painful orolabial lesions for 7 days, which are indicative of orolabial herpes. Thus, an endoscopic evaluation was performed, and results showed severe erosive distal esophagitis. The patient received aggressive empirical antiviral treatment based on the endoscopic findings and the presence of concurrent herpes orolabial prior to confirmation via histological and serological examinations. In addition, our decision was based on the fact that there was no access to viral culture and PCR for the detection of HSV in oropharyngeal secretions or esophageal tissue specimens.

At present, the effect of antiviral treatment in immunocompetent patients is not fully elucidated due to the lack of comparative studies. Nevertheless, it should be considered based on symptoms and the severity of endoscopic findings to reduce recovery time and consequently prevent life-threatening complications such as upper gastrointestinal bleeding and esophageal perforation [5].

In addition, we searched MEDLINE to review relevant studies conducted in the literature from 1950 to 2019. The following keywords were used: "herpes simplex," "esophagitis," "immunocompetent," "child," and "adolescent." We included all cases of HE, as defined by the World Health Organization, in immunocompetent adolescents aged between 10 and 19 years. In total, 36 cases were identified [4,6-18]; the clinical characteristics of the patients are shown in Table 1 . The mean age was $15.097 \pm 2.736$ years, and the male: female ratio was 6.2:1. The most common manifestations were fever (69.44\%), odynophagia (69.44\%), and retrosternal pain $(55.55 \%)$. Coexisting herpetic orolabial and skin lesions were observed in $11(30.55 \%)$ cases. The most common endoscopic lesions were numerous ulcers $(79.41 \%)$, whitish exudates (47.05\%), and erythematous mucosa (35.29\%). The most frequently affected sites were the distal (54.54\%) and middle (45.45\%) esophagus, and the whole 


\section{Case Reports in Gastroenterology}

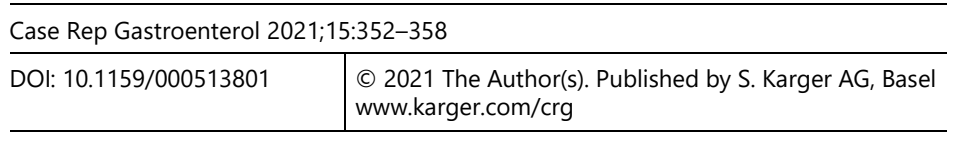

Koutsoumourakis et al.: Rare Etiology of Odynophagia in a Female Adolescent

esophagus was involved in 12 (36.36\%) patients. Diagnosis was made via histopathologic examination in $14(33.33 \%)$ cases, and $9(27.27 \%)$ patients had positive immunohistochemical staining results. HSV was identified via viral culture from esophageal brushing or using biopsy specimens in 26 (78.78\%) and via serology (high IgM antibody titer or seroconversion) in 12 $(36.36 \%)$ cases. In 5 of $36(13.88 \%)$ patients, the diagnosis was made via HSV genome detection using PCR in esophageal biopsy samples. Although this method had a high sensitivity $(94.7 \%)$ and a negative predictive value (96\%), it is not widely available [20]. Finally, 23 $(69.69 \%)$ patients received antiviral therapy with a mean symptoms-relief period of $7.38 \pm$ 5.23 days.

Three male patients with a mean age of 13.63 years had concomitant EoE and HE, and an 11-year-old boy presented with EoE after HE resolution. To date, whether HSV infection induces EoE or whether EoE is a risk factor for HE is not fully elucidated. The first theory proposed that HSV impairs the integrity of the esophageal mucosa barrier, thereby easing the passage of food antigens, which can trigger the $\mathrm{Th}_{2}$ immune response. This mechanism in turn boosts esophageal eosinophilic mucosal inflammation [20]. The second theory shows that EoE precedes HSV infection, considering that the damaged esophageal mucosal is exposed to the virus [19]. In EoE, the widening of paracellular spaces, low levels of tight junction proteins, and presence of desmosomes with structural abnormalities are indicative of mucosal barrier loss [21].

Nevertheless, if HE is suspected in an adolescent, an extensive workup should be performed to rule out a coexisting primary or secondary immunodeficiency disorder (including HIV infection). Moreover, at least 10 biopsy samples should be collected from the edge of the ulcers for histologic evaluation and viral culture or PCR assays. A follow-up EGD should be performed within 8 weeks to rule out EoE.

\section{Statement of Ethics}

A written informed consent for the publication of this case report and any accompanying figures was obtained from the patient's parents.

\section{Conflict of Interest Statement}

The authors have no conflicts of interest to declare.

\section{Funding Sources}

No funding was received for this study.

\section{Karger'=}




\section{Case Reports in Gastroenterology}

Case Rep Gastroenterol 2021;15:352-358

DOI: $10.1159 / 000513801$

(C) 2021 The Author(s). Published by S. Karger AG, Basel www.karger.com/crg

Koutsoumourakis et al.: Rare Etiology of Odynophagia in a Female Adolescent

\section{Author Contributions}

A.K.: wrote the manuscript, performed literature search, made revisions, and submitted the manuscript. M.S., A.G., and M.F.: provided critical feedback on the manuscript.

\section{References}

1 Harris J, Smith T, Preis J. Intractable hiccups due to herpetic esophagitis in an immunocompromised patient. IDCases. 2016 Feb;4:34-7.

2 Grudell AB, Mueller PS, Viggiano TR. Black esophagus: report of six cases and review of the literature, 19632003. Dis Esophagus. 2006;19(2):105-10.

3 Genereau T, Rozenberg F, Bouchaud O, Marche C, Lortholary O. Herpes esophagitis: a comprehensive review. Clin Microbiol Infect. 1997 Aug;3(4):397-407.

4 Canalejo E, García Durán F, Cabello N, García Martínez J. Herpes esophagitis in healthy adults and adolescents: report of 3 cases and review of the literature. Medicine (Baltimore). 2010 Jul;89(4):204-10.

5 Iriarte Rodriguez A, Frago Marquinez I, de Lima Pina GP. A case report: asymptomatic esophageal eosinophilia after herpes simplex esophagitis. Controversies in the therapeutic approach. Rev Esp Enferm Dig. 2018 Jul;110(7):471-2.

6 Machicado JD, Younes M, Wolf DS. An unusual cause of odynophagia in a patient with eosinophilic esophagitis. Gastroenterology. 2014 Jul;147(1):37-8.

7 Al-Hussaini AA, Fagih MA. Herpes simplex ulcerative esophagitis in healthy children. Saudi Journal of Gastroenterology. 2011;17(5):353-6. https://doi.org/10.4103/1319-3767.84496.

8 Lindberg GM, Van Eldik R, Saboorian MH. A case of herpes esophagitis after fluticasone propionate for eosinophilic esophagitis. Nat Clin Pract Gastroenterol Hepatol. 2008 Sep;5(9):527-30.

9 Tzouvala M, Gaglia A, Papantoniou N, Triantafyllou K, Karamanolis G. Herpes simplex Virus Esophagitis in an Immunocompetent Patient with Ebstein-Barr Virus Infection. Case Rep Gastroenterol. 2008 Sep;2(3):451-5.

10 Khlevner J, Beneri C, Morganstern JA. Wrestling and herpetic esophagitis. Pediatr Infect Dis J. 2011 Oct;30(10):911-2.

11 de-la-Riva S, Munoz-Navas M, Rodriguez-Lago I, Carrascosa J, Idoate MA, Carias R. Herpetic esophagitis: a case report on an immunocompetent adolescent. Rev Esp Enferm Dig. 2012 Apr;104(4):214-7.

12 Zaja Franulovic O, Lesar T, Busic N, Tesovic G. Herpes simplex primo-infection in an immunocompetent host with eosinophilic esophagitis. Pediatr Int. 2013;55(3):e38-41. https://doi.org/10.1111/ped.12027.

13 Cristoforo TA, Rietsma K, Wilsey A, Swan EK, Wilsey M. Herpes Esophagitis With Concomitant Eosinophilic Esophagitis in a Child: A Case Report. Clin Pediatr (Phila). 2018 May;57(5):618-20.

14 Ramanathan J, Rammouni M, Baran J Jr, Khatib R. Herpes simplex virus esophagitis in the immunocompetent host: an overview. Am J Gastroenterol. 2000 Sep;95(9):2171-6.

15 Kato S, Yamamoto R, Yoshimitsu S, Shimazaki K, Ogawa S, Itoh K, et al. Herpes simplex esophagitis in the immunocompetent host. Dis Esophagus. 2005;18(5):340-4.

16 Kim J, Lee K, Lee W. A Case of Eosinophilic Esophagitis Associated with Herpes Esophagitis in a Pediatric Patient. Clin Endosc. 2019 Nov;52(6):606-11.

17 Berlin KE, Weisgerber M, Loconto E. Case 2: Epigastric Pain in a 14-year-old Boy. Pediatr Rev. 2018 Nov;39(11):562-4.

18 Fritz J, Lerner D, Suchi M. Herpes Simplex Virus Esophagitis in Immunocompetent Children: A Harbinger of Eosinophilic Esophagitis? J Pediatr Gastroenterol Nutr. 2018 Apr;66(4):609-13.

19 Squires KA, Cameron DJ, Oliver M, da Fonseca Junqueira JC. Herpes simplex and eosinophilic oesophagitis: the chicken or the egg? J Pediatr Gastroenterol Nutr. 2009 Aug;49(2):246-50.

20 Jazeron JF, Barbe C, Frobert E, Renois F, Talmud D, Brixi-Benmansour H, et al. Virological diagnosis of herpes simplex virus 1 esophagitis by quantitative real-time PCR assay. J Clin Microbiol. 2012 Mar;50(3):948-52.

21 Blevins CH, Iyer PG, Vela MF, Katzka DA. The Esophageal Epithelial Barrier in Health and Disease. Clin Gastroenterol Hepatol. 2018 May;16(5):608-17. https://doi.org/10.1016/j.cgh.2017.06.035. 

www.karger.com/crg

Koutsoumourakis et al.: Rare Etiology of Odynophagia in a Female Adolescent

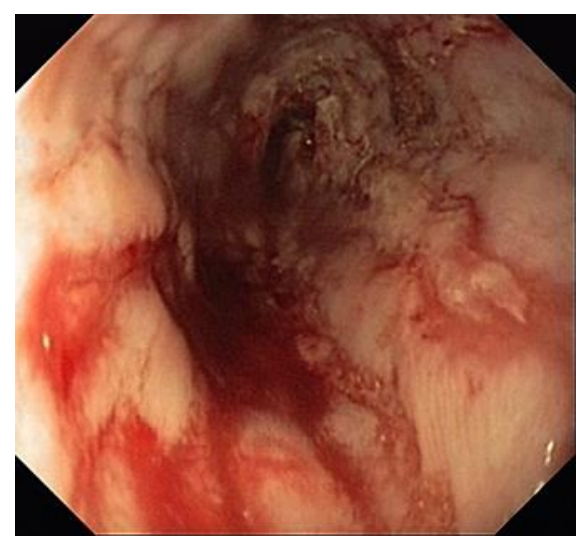

Fig. 1. Endoscopic appearance on admission.

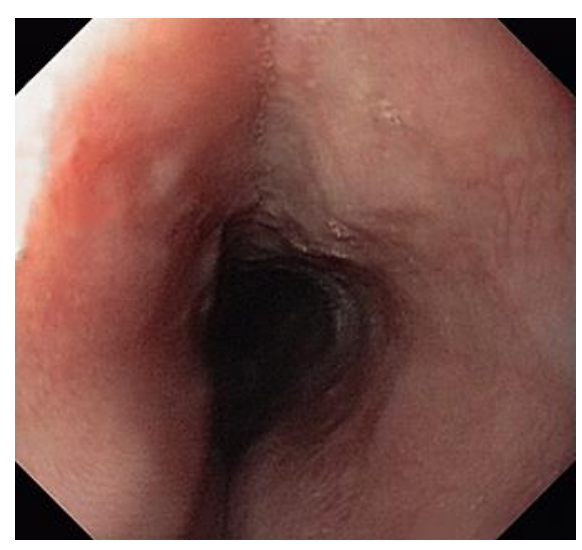

Fig. 2. Endoscopic appearance in the fourth week after discharge.

\section{Karger's}




\section{Case Reports in Gastroenterology}

\begin{tabular}{l|l}
\hline Case Rep Gastroenterol 2021;15:352-358 \\
\hline DOI: 10.1159/000513801 & $\begin{array}{l}\text { (c) 2021 The Author(s). Published by S. Karger AG, Basel } \\
\text { www.karger.com/crg }\end{array}$ \\
\hline
\end{tabular}

Koutsoumourakis et al.: Rare Etiology of Odynophagia in a Female Adolescent

Table 1. Clinical characteristics of HSV esophagitis in the immunocompetent adolescents

\begin{tabular}{|c|c|c|c|c|c|c|c|c|c|}
\hline No. & Age & Sex & Symptoms & $\begin{array}{l}\text { Endoscopic } \\
\text { findings }\end{array}$ & Location & $\begin{array}{l}\text { Other } \\
\text { herpetic le- } \\
\text { sions }\end{array}$ & Diagnosis & $\begin{array}{l}\text { Antiviral } \\
\text { treatment }\end{array}$ & $\begin{array}{l}\text { Days of res- } \\
\text { olution }\end{array}$ \\
\hline 1 & 10 & M & $\mathrm{F}, \mathrm{RP}$ & U, Ex & NR & No & C, S & No & 5 \\
\hline 2 & 12 & M & $\mathrm{F}, \mathrm{V}, \mathrm{He}$ & U, Ex & $\mathrm{D}$ & Yes & $\mathrm{C}$ & Yes & 1 \\
\hline 3 & 10 & M & $\mathrm{F}, \mathrm{RP}, \mathrm{O}$ & NR & NR & No & C, S & NR & NR \\
\hline 4 & 12 & M & $\mathrm{F}, \mathrm{RP}$ & NR & NR & Yes & $\mathrm{C}$ & NR & NR \\
\hline 5 & 19 & M & F, O, BWL, URTI & $\mathrm{U}$ & $\mathrm{D}$ & Yes & C, S & No & 17 \\
\hline 6 & 18 & M & 0, Dy & $\mathrm{U}$ & $\mathrm{Mi}$ & No & $\mathrm{H}$ & No & NR \\
\hline 7 & 19 & M & $\mathrm{F}, \mathrm{O}$ & $\mathrm{U}$ & $\mathrm{Mi}$ & No & $\mathrm{C}$ & No & NR \\
\hline 8 & 14 & M & F, RP, O, BWL, URTI & U, Ex & $\mathrm{E}$ & Yes & $\mathrm{C}$ & No & 7 \\
\hline 9 & 17 & M & $\mathrm{F}, \mathrm{RP}, \mathrm{O}, \mathrm{BWL}$ & $\mathrm{U}$ & $\mathrm{Mi}, \mathrm{D}$ & No & $\mathrm{C}$ & No & 5 \\
\hline 10 & 17 & M & O, BWL & $\mathrm{U}$ & $\mathrm{D}$ & No & C, S, IH & NR & 18 \\
\hline 11 & 19 & $\mathrm{~F}$ & $\mathrm{~F}, \mathrm{RP}, \mathrm{O}$ & R, Ex & Mi, D & No & $\mathrm{C}, \mathrm{S}, \mathrm{H}, \mathrm{IH}$ & Yes & 17 \\
\hline 12 & 19 & M & F, O, Ep, URTI & $\mathrm{U}$ & $\mathrm{P}$ & Yes & $\mathrm{C}, \mathrm{S}$ & Yes & 4 \\
\hline 13 & 14 & M & $\mathrm{F}, \mathrm{O}, \mathrm{V}$ & $\mathrm{U}$ & Mi, D & No & C, H, IH & Yes & 1 \\
\hline 14 & 14 & $\mathrm{~F}$ & F, RP, Dy & $\mathrm{R}, \mathrm{Er}$ & $\mathrm{E}$ & No & $\mathrm{H}$ & Yes & 1 \\
\hline 15 & 17 & M & RP, Dy, V, URTI & $\mathrm{U}$ & Mi, D & Yes & $\mathrm{C}$ & Yes & 10 \\
\hline 16 & 11 & M & $\mathrm{F}, \mathrm{RP}, \mathrm{O}, \mathrm{Dy}$ & $\mathrm{U}, \mathrm{R}$ & $\mathrm{Mi}, \mathrm{D}$ & Yes & C, S, H, IH & Yes & 10 \\
\hline 17 & 14 & M & F, RP, O, Ep, POI & $\mathrm{U}$ & $\mathrm{D}$ & No & $\mathrm{C}, \mathrm{S}, \mathrm{H}$ & Yes & 10 \\
\hline 18 & 17.6 & M & $\mathrm{RP}, \mathrm{D}$ & Er, Ex, R & $\mathrm{D}$ & No & $\mathrm{C}$ & Yes & NR \\
\hline 19 & 11.6 & M & $F, R P, D, V$ & $\mathrm{U}$ & $\mathrm{Mi}, \mathrm{D}$ & No & $\mathrm{C}$ & Yes & NR \\
\hline 20 & 15.4 & M & $\mathrm{RP}, \mathrm{O}$ & Ex & $\mathrm{E}$ & No & $\mathrm{C}$ & Yes & NR \\
\hline 21 & 13.4 & M & RP, O, BWL & U, Ex & $\mathrm{E}$ & No & $\mathrm{C}$ & Yes & NR \\
\hline 22 & 15.8 & $\mathrm{~F}$ & $\mathrm{~F}, \mathrm{O}$ & U, R, Er & $\mathrm{E}$ & No & $\mathrm{C}$ & Yes & NR \\
\hline 23 & 11.5 & M & $F, D, V$ & U, Ex & $\mathrm{E}$ & No & $\mathrm{C}$ & Yes & NR \\
\hline 24 & 16.2 & M & $\mathrm{RP}, \mathrm{D}, \mathrm{V}$ & $\mathrm{R}, \mathrm{Er}, \mathrm{Ex}$ & $\mathrm{E}$ & No & $\mathrm{C}$ & Yes & NR \\
\hline 25 & 14 & M & $\mathrm{F}, \mathrm{O}$ & Ex & $\mathrm{E}$ & No & H, IH, PCR & Yes & NR \\
\hline 26 & 16 & M & O, Dy & $\mathrm{U}$ & $\mathrm{E}$ & No & $\mathrm{C}, \mathrm{S}$ & Yes & NR \\
\hline 27 & 13 & M & F, O, Ep & $\mathrm{Er}$ & $\mathrm{Mi}, \mathrm{D}$ & Yes & $\mathrm{C}, \mathrm{S}, \mathrm{H}$ & Yes & 10 \\
\hline 28 & 18 & M & F, O, D, Ep, V & U, R, Ex & $\mathrm{E}$ & Yes & $\mathrm{H}, \mathrm{IH}$ & Yes & 14 \\
\hline 29 & 17 & $\mathrm{~F}$ & $\mathrm{RP}, \mathrm{Ep}, \mathrm{He}$ & $\mathrm{U}, \mathrm{R}$ & Mi, D & No & S, H, IH, PCR & No & NR \\
\hline 30 & 16 & M & $\mathrm{F}, \mathrm{RP}, \mathrm{O}$ & $\mathrm{U}$ & $\mathrm{Mi}, \mathrm{D}$ & No & $\mathrm{C}, \mathrm{H}$ & Yes & 5 \\
\hline 31 & 13 & M & $\mathrm{F}, \mathrm{RP}, \mathrm{O}$ & U, R, Ex & $\mathrm{E}$ & No & $\mathrm{C}, \mathrm{S}, \mathrm{IH}$ & No & NR \\
\hline 32 & 12 & M & $\mathrm{F}, \mathrm{RP}, \mathrm{O}$ & $\mathrm{U}, \mathrm{R}$ & $\mathrm{E}$ & Yes & $\mathrm{S}$ & Yes & NR \\
\hline 33 & 17 & M & $\mathrm{F}, \mathrm{RP}, \mathrm{O}$ & U, R, Ex & $\mathrm{Mi}, \mathrm{D}$ & No & PCR & No & NR \\
\hline 34 & 16 & M & F, O, Dy & U, R, Ex & $\mathrm{Mi}, \mathrm{D}$ & No & PCR & No & NR \\
\hline 35 & 19 & $\mathrm{~F}$ & Dy & U, Ex & $\mathrm{Mi}, \mathrm{D}$ & No & $\mathrm{H}, \mathrm{IH}$ & Yes & 10 \\
\hline 36 & 15 & M & 0 & U, Ex & Mi, D & Yes & PCR & Yes & 3 \\
\hline
\end{tabular}

BWL, body weight loss; C, culture; D, distal esophagus; Dy, dysphagia; E, entire esophagus; Ep, epigastric pain; Er, erosions; Ex, exudates; F, fever; H, histology; He, hematemesis; IH, immunohistochemistry; Mi, mid-esophagus; NR, not reported; O, odynophagia; P, proximal esophagus; PCR, polymerase chain reaction; POI, poor oral intake; R, redness of esophageal mucosa; RP, retrosternal pain; S, serology; U, ulcers; URTI, upper respiratory tract infection; V, vomiting. 